\title{
Philosophical Bases for Conceptions of Senior Secondary Level Student Evaluation in Art Education in Britain and North America \\ Fion Blaikie
}

\section{Introduction}

There is ongoing conflict in the field of art education concerning what kind of art knowledge is most worthwhile. Consequently, art education is represented by a plurality of values and value systems. This conflict concerning the epistemological foundations of art education is reflected in models for evaluation.

The fundamental and ongoing debate is in determining the purpose of art education. In this connection, conceptions of evaluation and evaluation procedures have considerable impact in defining and determining the scope and purpose of art education. Thus, the problems of evaluation are linked in an essential way to the epistemological foundations and objectives of art education.

In addition to regional and national trends which represent a variety of positions concerning the purpose of art education, ideas are shared internationally, and in a cross-disciplinary way. Arguments are derived from related theoretical fields, such as aesthetics, philosophy, sociology, and politics. Some significant conceptions of knowledge in art education dominating the field in North America include discipline-based art education (Greer, 1984); a feminist emphasis in art education (Collins and Sandell, 1987); a child-centered conception of art education (Jeffers, 1990), which is linked to a studio-based conception of art education (Read, 1958; Michael, 1980), and a multi-cultural emphasis rooted in sociology and anthropology (Chalmers, 1981; McFee 1986). In Britain critical studies is dominant, and combines art, craft, design, art criticism, and art history (Taylor, 1986; Steers, 1987). On an international basis, radical postmodernist developments in both art and education have influenced many art educators.

\section{Purpose of the Study}

The purpose of this study is to examine the way in which theories about evaluation serve to further significant conceptions of art knowledge, and the way in which conceptions of art knowledge are defined indirectly by evaluation. I shall focus on those conceptions of art knowledge and evaluation which are visible and significant in the literature. Specifically, I shall examine current positions in North America and Britain, which address art education and evaluation procedures for senior secondary level students. 


\section{Preamble to Statement of the Problem}

In recent history in North America, evaluation in art education has been almost taboo, particularly since the trend established by Lowenfeld (1947) in Creative and Mental Growth, against imposing adult conceptions of art on students. This reluctance to evaluate art learning is evident in the literature, both past and present. For example, Godfrey (1964) asserts that self evaluation through self reflection is the best alternative in evaluation in art. Similarly, Burkhart (1965) maintains that from 1957 on there was a movement away from the notion of developing aesthetic criteria for evaluating art products, to one based on the nature of the individual student's strategies and procedures.

However, with the current trend toward a more content based curriculum in art in North America, as Maling (1983) asserts, art educators are moving away from the trend which saw evaluation as

distorting the processes of both art and teaching/learning in pursuit of a 'scientific' truth. Such a reaction, however relevant twenty years ago, is now, I believe, outmoded: the field of evaluation has shifted; the demands for evaluation have increased; the challenge is for art educators to respond --and there are now evaluative approaches available to the profession that can work for it rather than against it. (p. 29)

In light of Maling's proposal, Rubin (1982) describes a method for naturalistic evaluation, which includes informal evaluation through class critiques, and the evaluation of written work, while Day (1985) proposes a combination of formal and informal procedures for evaluating discipline-based art education.

In Britain, formal evaluation in art education has existed for so long that past and present art educators seem more concerned about the form which evaluation should take, rather than whether art should be evaluated. For example, Carwyn and Goddard (1977) are concerned about improving perceptions of the GCE examinations, while Aylward (1971) examines which qualities are evaluated in art: "a degree of intellectual thought; a capacity for original thought; a sound knowledge of materials and constructional processes; an understanding of human needs" (p. 37). Beaghen (1964) declares that evaluation should be formative rather than summative, and should not drive the content of art learning.

\section{Statement of the Problem}

The problem is in determining the relation between conceptions of art knowledge and evaluation in art education. Five issues define the problem.

First, the activity of evaluation is fundamental in both the arts and in education. Yet many art educators, particularly in North America, are

Working Papers in Art Education 1991 
reluctant to evaluate student learning in art. Evaluating art work is considered by some to be a potential affront to the individual student's feelings. It is acceptable to evaluate the student in other subject areas, even those where a subjective response is required, such as creative writing, as well as mathematics, biology, and so on. This implies that the student is more sensitive about his or her art work than work produced in any other subject at school, and that the student is less disappointed when achieving poor results in other subjects. Thus, the notion of evaluation is problematic for many art educators, although it is a basic and fundamental activity in the arts in the real world, and in education.

Second, it is and has been difficult to define boundaries in art education, and therefore to define an exclusive conception of art knowledge. When it is difficult to define boundaries, and thus goals or purposes, it is difficult to evaluate, because there are no parameters upon which to operate. At the heart of this problem lie assumptions and varied perceptions of the role of art in the school, and the purpose of art education.

Third, problems seem to arise from the nature of making an aesthetic evaluation. As Burkhart (1965) points out, the problem is in deciding the meaning of an aesthetic judgement. As I see it, especially among North American art educators, the problem seems to lie in confusion between aesthetic and educational judgements, and a lack of confidence in making aesthetic judgements. It is essentially the educational value of aesthetic judgements which is held in question, as well as the validity of the aesthetic judgement itself. For example, Burkhart (1965) states explicitly that judgements about art products are problematic as they are subjective. This, Burkhart maintains, is because no objective or stable aesthetic criteria can be applied to the evaluation of art products.

A related problem seems to be that students and teachers alike may perceive the meaning of aesthetic quality in different ways. While subjective educational judgements may be made--for example, determining whether Mary is making an effort--aesthetic judgements made by art teachers are today still to some extent taboo because they suggest the Lowenfeldian notion that another (adult's) opinion is an unwelcome imposition, and anyway that what is important is not what is produced, but whether the experience of making the art product was worthwhile.

The idea that teachers cannot and should not make aesthetic evaluations is supported by Quast (1985), who maintains that grades "threaten the individual" (p. 149), and that art should be a place within the school system where "there should be a refuge from standard systems of marking" (p. 149). Quast's lack of a conception of art knowledge is implicit in his theories on evaluation, but conveniently he states explicitly that art knowledge is something to be determined by the student, rather than the teacher. 
Fourth, problems seem to originate from the methods adopted for evaluation in art education. Hausman (1988) declares that these problems originate because the means adopted are inappropriate and antithetical to the values of art. Hausman believes that this is because the qualitative nature of art is forced into the quantitative measurement of other kinds of learning. Hamblen (1988), for example, conceives of art education as an experiential subject, unique in the curriculum, and threatened by evaluation. She limits evaluation to the notion of testing, as if no other alternatives were possible, such as the British system based on moderators and art teachers assessing art work together. Hamblen maintains that "testing is being proposed as a means to legitimate art study" (p. 11). In terms of art knowledge, she writes that in testing, art learning becomes a "boundaried entity that is carefully managed with standardized means and objectively testable ends" (p. 11).

On the other hand, British art educator Duthie (1969) acknowledges that the design of any test is a subjective, creative act, even when it is linked to instructional objectives--or even standardized tests. Yet Duthie maintains that when impressions of judges (that is, moderators and art teachers) are matched as a basis for assessment and evaluation, it is possible to quantify the uncountable. Similarly, Richardson (1980) declares that although the arts

exist in what might be called the aesthetic realm of the human psyche and experience... This realm is characterized by its involvement with the emotional, the emotive, the subjective and the irrational. But it is quite possible to be clear thinking and rational about irrational things. (p. 3)

Richardson maintains that it is nonsense to ask whether it is ethical to evaluate. He states: "It is a psychological impossibility for a conscious human being not to evaluate every situation in which he/she is" (p. 5). Richardson believes that evaluation should focus on what has been learned. $\mathrm{He}$ believes that an important aspect of art knowledge to be evaluated has to do with learning to express ideas verbally about art:

We must work diligently to refine our verbal expression about art--define our terms and use them consistently. Literary and music critics seem to have less of a problem in this regard. ... That it must be possible to break through the communication barrier is shown by the way psychologists, who deal (as artists do) with the irrational (or arational or non rational, less loaded terms) are able to communicate pretty well. (p. 6)

Fifth, and finally, in adopting and implementing an evaluation method, one is also adopting the conception of art knowledge of the person(s) who proposed the evaluation method. In this regard, there has been much cross-disciplinary influence in the field of art education, so that often conceptions of art knowledge and of evaluation are determined by other

Working Papers in Art Education 1991 
agendas, such as theories of aesthetics, sociology, politics, philosophy, and postmodernism. Theories which are associated with art education need to be evaluated in terms of the implications of conceptions of evaluation associated with that position.

Smith (1983) proposes radical changes in art education that relate to the problematic relationship between art knowledge and evaluation in the postmodern context: He believes current conceptions of art knowledge are inadequate. Like Efland (1976), Smith maintains that a school art style persists which is remote from both students' interests, and the real art world. According to Smith, a better conception of art knowledge would be one which deals with art as problem finding, rather than problem solving. The evaluation and examination of students should address this phenomenon, and also should allow "young people to sense the genuine values (of art)" (p. 84).

\section{Conclusion}

I seek to analyse which philosophies of mind and aesthetics are reflected in significant positions in the field of art education, with regard to both curriculum structure and evaluation. I will complete my investigation by arguing for a defensible conception of knowledge and evaluation at the senior secondary level. I shall address my argument specifically to the conflicting values inherent in current trends in art education, and to the sometimes confusing genre of postmodernism, as it affects art, culture, and education. My conclusions will focus on the implications of conceptions of knowledge for evaluation procedures in teaching practice, including the fit between ideology and evaluation, and which notions of evaluation a particular philosophical position can sustain and support.

\section{References}

Aylward, B. T. (1971). The Oxford 'A' level examination in design. Studies in Design Education and Craft, 4 (1), 35-44.

Beaghen, G. (1964). We should stop working for examinations: We should start examining work. Athene, 11, 6-10.

Bennett, G. (1988). GCSE art and design curriculum, the new orthodoxy? Curriculum, 9 (3), 140-146.

Burkhart, R. (1965). Evaluation of learning in art. Art Education, 19 (4). 3-5.

Carwyn, R. and Goddard, I. (1977, November 25). Art for life's sake. Times Education Supplement, 3259, p. 19.

Chalmers, G. (1981). Art education as ethnology. Studies in Art Education, $22(3), 6-14$. 
Collins, G. and Sandell, R. (1987). Women's achievements in art: An issues approach for the classroom. Art Education, 40 (3), 12-21.

Day, M. D. (1985). Evaluating student achievement in a discipline-based art programs. Studies in Art Education, 26 (4), 232-240.

Duthie, R. K. (1969). An investigation into marking art examinations. British Journal of Educational Psychology, 39 (3), 316-320.

Efland, A. (1976). The school art style: A functional analysis. Studies in Art Education, 17 (2), 37-44.

Eisner, E. (1971). How can you measure a rainbow? Tactics for evaluating the teaching of art. Art Education, 24 (5), 36-39.

Fortune, N. R. (1970, September 25). Craftwork, design, communication, and application. Times Educational Supplement, 2888, p. 46.

Godfrey, M. E. (1964). Grading and pupil evaluation. Art Education, 17 (3), 17-20.

Greer, D. (1984). A discipline-based view of art education: Approaching art as a subject of study. Studies in Art Education, 25 (4), 212-218.

Hamblen, K. (1988). If it is to be tested, it will be taught: A rationale worthy of examination. Art Education. 41 (5), 57-62.

Hausman, J. (1988). Back to the future: Reflections on present-day emphases in curriculum and evaluation. Art Education, 41 (2), 36-41.

Jeffers, C. (1989). Child-centered and discipline-based art education: Meaning and metaphors. Art Education, 43 (2), 16-21.

Lowenfeld, V. (1947). Creative and mental growth. New York: MacMillan.

Maling, J. (1983). Evaluation in art education. Journal of the Institute of Art Education, 7 (2), 19-40.

McFee, J. (1986). Cross-cultural inquiry into the social meaning of art: Implications for art education. Journal of Cross-Cultural and Multicultural Research in Art Education, 4 (1), 6-16.

Michael, J. (1980). Studio art experience: The heart of art education. Art Education, 33 (2), 15-19.

Quast, W. (1985). Evaluation in art. Lutheran Education, 120, 148-149.

Read, H. (1958). Education through art. London: Faber and Faber. 
Rubin, B. M. (1982). Naturalistic evaluation: Its tenets and applications. Studies in Art Education, 24 (1), 57-62.

Richardson, D. (1980). Evaluation in visual art education. Australian Society for Education through Art Bulletin, 18 (4), 3-8.

Ross, A. (1985). Away with marks! Manitoba Teacher, 64 (1), 15.

Smith, F. (1983). Preparing for examination in art. Educational Analysis, 5 (2), $77-87$

Smith, R. (1989). The sense of art: A study in aesthetic education. New York: Routledge.

Steers, J. (1987). Art, craft and design education in Great Britain: A summary. Canadian Review of Art Education, 15 (1), 15-20.

Stevenson, M. (1983). Problems of assessment and examination in art education. Journal of Art and Design Education, 2 (3), 296-317.

Taylor, R. (1986). Educating for art: Critical response and development. London: Longman. 